\title{
Biodiversity of Bali Banana (Musaceae) and its Usefulness
}

\author{
I Nyoman Rai ${ }^{1,2^{*}}$, Fenny M. Dwivany ${ }^{1,3}$, Agus Sutanto ${ }^{4}$, Karlia Meitha ${ }^{1,3}$, I Made Sukewijaya ${ }^{1,2}$, I Nyoman Gede Ustriyana ${ }^{1,2}$ \\ ${ }^{1}$ Bali International Research Center for Banana, Udayana University, Bali, Indonesia \\ ${ }^{2}$ Faculty of Agriculture, Udayana University, Bali, Indonesia \\ ${ }^{3}$ School of Life Sciences and Technology, Institut Teknologi Bandung, Bandung, Indonesia \\ ${ }^{4}$ Indonesia Tropical Fruits Research Institute, Solok, Indonesia
}

ARTICLE INFO

Article history:

Received February 10, 2017

Received in revised form November 17, 2017

Accepted December 20, 2017

\section{KEYWORDS:}

Bali banana,

Diversity,

biu,

Utilization,

Cultural ceremony

\begin{abstract}
Banana (Musa spp.) is one the most important agriculture commodities in Indonesia. Archeological and molecular evidences suggest that speciation of this herb occurred in Indonesia, leading to the high diversity in the archipelago. In Bali Island, banana is not only sought for food but as well as for their symbolic role in religious and cultural ceremonies. However, the high demand for bananas in Bali is not yet supported by the adequate production of local farms. This presented study aimed to investigate the diversity of banana cultivars or sub-species in Bali and its usefulness to determine preferable cultivars to cultivate. We recorded and characterized 43 banana cultivars in 10 villages that represent the 8 regencies and 1 city of Bali province. Out of the 43 cultivars, 7 were highly used and at least one cultivar was discovered in each of the studied village. The presence of these cultivars in the study areas were confirmed by site visit and characterization of the fruits. Among the highly ranked cultivars or species, only biu kayu is unique to Bali as it was not found in the closest provinces of East Java and Madura. Hence, the results suggested that to improve the cultivation and production of these 7 highly used cultivars could be an appropriate solution to meet Bali demand of bananas. Furthermore, cultivating biu kayu would also help conservation effort since this cultivar is also currently listed as a rare genetic resource.
\end{abstract}

\section{Introduction}

Indonesia possesses an estimated of 25,000 flowering plants with $55 \%$ of them are endemic, making the country as one of the world's centers for agro-biodiversity of plant cultivars and domesticated livestock (Convention on Biological Diversity 2017). Among the endemic plant species in Indonesia, the archaeologists suggest that the speciation of bananas occurred in Papua New Guinea and east of Indonesia following further differentiation and distribution to Southeast Asia and then worldwide (De Langhe et al. 2013). Furthermore, banana domestication in Southeast Asia, based on the study of nuclear and chloroplast genes, is suggested to have commenced at least 5000 years ago (Li et al. 2013). These findings confirm the important and historical relation between Indonesian people with banana.

Banana is an essential staple food, even in Africa banana including the fourth food source after rice, wheat and corn (Honfo et al. 2011; Fandika et al.

\footnotetext{
* Corresponding Author.

E-mail Address: rainyoman@unud.ac.id
}

2014). Banana is also a crucial component of food and economic sectors in many areas in Indonesia. Especially in Bali, bananas also play an important role in cultural activities as well as in religious ceremonies (Lugrayasa 2004). The various uses of bananas in Bali are displayed in Figure 1. However, the mismatch between supply and demand in the island has caused the locals to rely on bananas supply from outside, especially from Java (Suparyana 2016). It was reported that generally a banana seller in a traditional market in Denpasar needs to buy at least 300 bunches of bananas from Java in every 10 days (Habit 2016). The limited local supply indicates low banana production in the province that might be a consequence of lack of knowledge among farmers of banana cultivars with high user (economic) value. This might be problematic for the farmers to decide of which banana cultivars to cultivate that are highly demanded by the locals.

Hence, this presented study aimed to investigate the diversity of bananas in Bali and utilization of its fruits to suggest which cultivars would be economically wise to cultivate. By associating the diversity in each study area with highly used banana cultivars, the data would allow farmers and policy makers to consider the best cultivars to cultivate in a certain areas. 

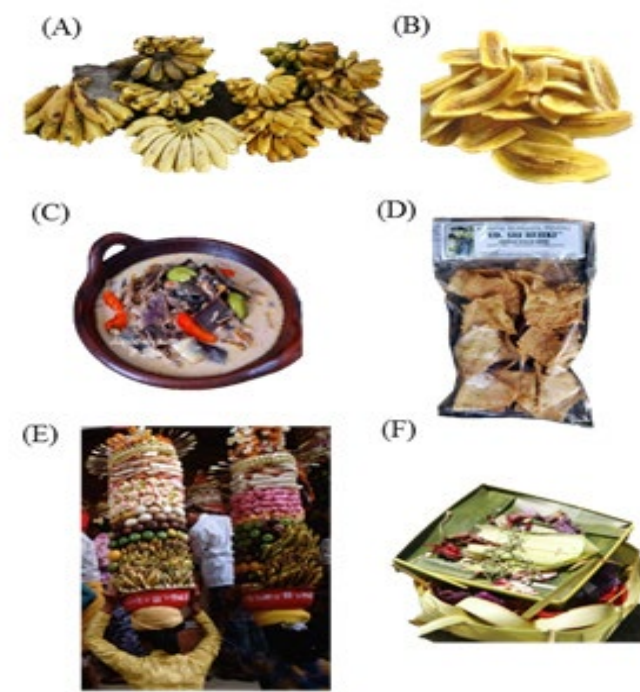

(G)
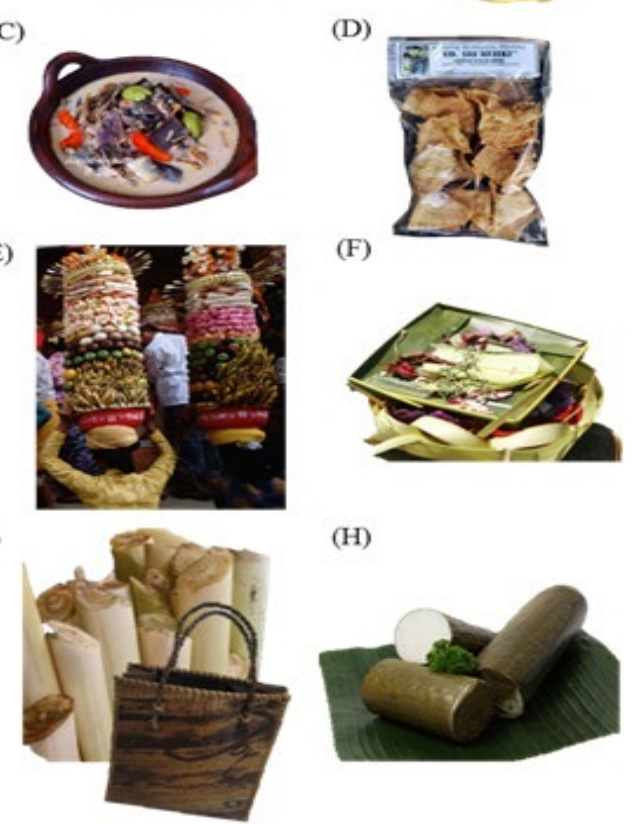

(H)

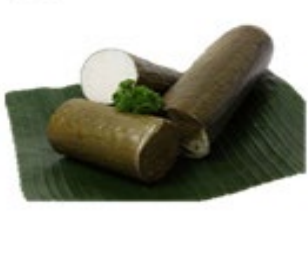

Figure 1. The diverse use of bananas in daily life of Balinese. The role of bananas as food are represented in (A$D)$, the fruits could be consumed as fresh (A) or cooked such as into chips (B). The flower is also edible, which often cooked into soup (C) and the corms processed into chips (D). Moreover, bananas play important role as one of the symbolic fruits in cultural and religious ceremonies (E-F). The leaf is often used as food wrapping $(H)$, while the stem is useful as materials for woven bag $(G)$

\section{Materials and Methods}

\subsection{Study Areas}

The study was conducted on July-August 2017 in 10 villages, each representing 8 regencies and 1 city of Bali province. The villages were chosen based on the recommendations from the representative of local government or department of agriculture. Some factors were considered prior to recommending such as: the total area of banana farms in the village, production of banana fruits and banana-based products, and the overall health of bananas in the area. Except for Celuk village in the regency of Gianyar, this was chosen due to the presence of banana germplasm collection of Bali Agricultural Technology Research Centre (Balai Pengkajian Teknologi Pertanian/BPTP Bali). Representing villages of each regent and city are displayed in Table 1.

\subsection{Characterization of Bananas in Bali}

Prior to the investigation of presence banana cultivars in each area of study, we interviewed local people to generate a preliminary list of cultivars to
Table 1. Representing villages of each regent and city. The survey was conducted in chronological order, started in village number 1 to 9

\begin{tabular}{|c|c|c|}
\hline District/City & Village & $\begin{array}{l}\text { Coordinate of Global } \\
\text { Positioning System }\end{array}$ \\
\hline Denpasar & Penatih & $\begin{array}{l}8^{\circ} 36^{\prime} 28.79^{\prime \prime} \mathrm{S} \\
115^{\circ} 14^{\prime} 14.87^{\prime \prime} \mathrm{E}\end{array}$ \\
\hline \multirow[t]{2}{*}{ Gianyar } & Kerta & $\begin{array}{l}8^{\circ} 19^{\prime} 49.64 " \mathrm{~S} \\
115^{\circ} 17^{\prime} 32.69 " \mathrm{E}\end{array}$ \\
\hline & Celuk & $\begin{array}{l}8^{\circ} 36^{\prime} 5.59 " \mathrm{~S} \\
115^{\circ} 15^{\prime} 53.85 \text { ”E }\end{array}$ \\
\hline \multirow[t]{2}{*}{ Klungkung } & Besan & $\begin{array}{l}8^{\circ} 31^{\prime} 5.73^{\prime \prime} \mathrm{S} \\
115^{\circ} 27^{\prime} 5.85^{\prime \prime} \mathrm{E}\end{array}$ \\
\hline & Pesinggahan & $\begin{array}{l}8^{\circ} 32^{\prime} 58.88^{\prime \prime S} \\
115^{\circ} 27^{\prime} 27.02 " \mathrm{E}\end{array}$ \\
\hline Karangasem & Rendang & $\begin{array}{l}8^{\circ} 25^{\prime} 41.02 ” S \\
115^{\circ} 25^{\prime} 7.79 " \mathrm{E}\end{array}$ \\
\hline Bangli & Jehem & $\begin{array}{l}8^{\circ} 24^{\prime} 54.90^{\prime \prime S} \\
115^{\circ} 22^{\prime} 15.16^{\prime \prime} \mathrm{E}\end{array}$ \\
\hline Buleleng & Anturan & $\begin{array}{l}8^{\circ} 9,12.42 ” S \\
115^{\circ} 33^{\prime} 4.93 " \mathrm{E}\end{array}$ \\
\hline Badung & Abiansemal & $\begin{array}{l}8^{\circ} 32^{\prime} 15.60 " \mathrm{~S} \\
115^{\circ} 12^{\prime} 51.66 " \mathrm{E}\end{array}$ \\
\hline Tabanan & Marga & $\begin{array}{l}8^{\circ} 25^{\prime} 51.67 " \mathrm{~S}, \\
115^{\circ} 10 ’ 34.55^{\prime \prime} \mathrm{E}\end{array}$ \\
\hline Jembrana & Bading Kayu & $\begin{array}{l}8^{\circ} 25^{\prime} 24.13^{\prime \prime S}, \\
114^{\circ} 54^{\prime} 59.59 " \mathrm{E}\end{array}$ \\
\hline
\end{tabular}

look for in the respective village. Precise locations of the cultivars were acquired from farmers, land owners, and common villagers. Characterization of the cultivar was performed as described in Descriptors for banana (Musa spp.) (IPGRI, CIRAD, and INIBAP 1996). The characterization was made by emphasizing to the descriptions of plant appearance, pseudo stem, petiole/midrib/leaf, inflorescence, bracts, male flower, and fruit. It was not always possible to characterize the cultivar based on all of the mentioned descriptors, depending on the availability of the organs at the time of study. Here, we focused the characterization on fruits as they are the most distinctive and mostly used organ of the plants.

\section{Results}

\subsection{Diversity of Bananas (Musaceae) in Bali}

The preliminary list of presence banana cultivars or sub-species served as the guidance when investigating each village. The taxonomy of discovered bananas was confirmed by Dr. Agus Sutanto (one of the authors and a senior banana researcher from ITFRI). We visited areas of the village, which according to the locals possessed quite some cultivars of banana. In total, there are 43 cultivars of Musa spp. presence in the studied villages of 8 regencies (Gianyar, Klungkung, Karangasem, Bangli, Buleleng, Badung, Tabanan, Jembrana) and 1 city (Denpasar) in Bali Province. The numbers of discovered banana cultivars are differ in each village, and unsurprisingly the highest diversity was found in the germplasm collection garden in Celuk. The list of discovered banana cultivars in each village is presented in Table 2. 


\subsection{Utilization of Bananas by the Locals}

Utilization of fruits of banana by the Balinese people is divided into 5 main categories, i.e. for cooking, dessert, ceremony, ornament, and medicine. Out of the 43 cultivars, 7 were highly used banana (or biu in the local dialect) cultivars, namely biu susu, biu lumut, biu buluh, biu kayu, biu saba, biu batu and biu mas. These are edible bananas except for biu batu, which are cultivated for the leaves. Table 2 presents the discovery locations of these highly used banana cultivars in Bali. The fruits of each highly used banana cultivars were characterized at Figure 2 and Supplemental Table 1.

\section{Discussion}

Banana holds crucial roles in the life of Balinese people. This herb is used in a range of activities as food, symbol in ceremonies, ornament, and other purposes. As a consequence, the daily demand of bananas in Bali local markets is always high and the island often imports from Java. This study was conducted to help improving Bali local production of bananas by investigating the diversity of Bali bananas. Combined with a good understanding of which cultivar is used for what purpose could help the farmers and all the parties involved in banana trade and industry. By cultivating and producing the highly used bananas cultivars in Bali, it is expected that the produces are able to enter the market straightforwardly as the locals are already familiar with.

Based on the preliminary interview to the locals and site visit to investigate the diversity of Bali bananas, we discovered 43 cultivars. They are spread over in the 8 regencies and 1 city of Bali province. The highest diversity of banana cultivars was found in Celuk village, since there was a germplasm collection garden. Overall, the diversity of banana cultivars in Bali ranges from only 5 cultivars in Marga village, Tabanan Regency, up to 16 were found in Besan Village, Klungkung Regency. From deep interviews with local informants, we got information that almost all parts of banana plant in Bali are useful, for example for food (mature and immature fruit, seedy fruit, terminal inflorescence/male bud, male flower, pseudo stem, and sucker/shoot), ornament/ decoration (flowers, inflorescence, leaves, and dried leaves), ceremonial and ritual (fruit, fruiting stalk, leaves, pseudo stem, leaf sheath and whole small plant), medicine (juice/sap of pseudo stem, stalk of inflorescence, roots, flowers, fruit skin, skin of pseudo stem, and young flower buds), fodders (pseudo stem, stalk of inflorescence and fruit, leaf, and rhizome) and for wrapping material (leaves). It is in accordance with Mohapatra et al. (2010) that in India whole banana plant is useful in food, feed, pharmaceutical, packaging, and many other industrial applications. Many of the social and religious ceremonies in India also require whole banana tree, apart from leaves and fruits. Kennedy (2009) stated, banana is the most recognizable of fruits and very well known as useful plant. Further analysis, showed that at least one cultivar of highly used bananas in the category of food, symbol in rituals, medicine and other purposes (Hidayat et al. 2017) was found in each village. Previously, Hapsari et al. (2017) indicated that the whole parts of bananas were also used in the four mentioned categories in East Java. Food category includes the use of the fruits as fresh and cooked food, medicine category covers the use of all parts of the plant for healing certain illnesses, and others include the use of plant parts as in decoration, ornamental garden, food wrapping, etc. Similarly as in Javanese culture (Solikin 2010), banana plants are believed to possess important symbolic meaning that the "behaviour" of the plants during growth could be adapted into practice in the daily life and ethics.

From site visit, we figured that banana cultivation in the surveyed villages was mostly conducted in backyards or smallholding farms $(<0.5 \mathrm{ha})$. Local informants also emphasized that bananas are not yet cultivated at big scale such as to supply industries. The villagers let bananas grow naturally on their land, or sometime intentionally plant the suckers, and rarely look after them until harvest time. During the site visits, it was clear that bananas were not one of the prioritized crops for most of the farmers. These herbs grew on abandon land, poorly spaced and sometimes no treatment whatsoever although some of them were clearly infected by pathogens.

Considering the high daily demand of bananas in the island, the time is ripe to appeal to the local farmers to prioritize bananas cultivation. The seven cultivars listed in this article are appropriate to choose, as the local consumers are already familiar with and regularly use them. A comprehensive farming method would allow optimum cultivation of these important bananas, leading to improvement of economic condition of framers and all involved parties in banana production or banana-based industries.

However, a further study with wider area to investigate the natural growing locations of biu saba, biu kayu, and biu buluh is required, since they were only found in germplasm garden in this study. Biu batu and biu susu were found in all of study area, indicating that the soil and microclimate condition of Bali in general are suitable for these cultivars or species. 


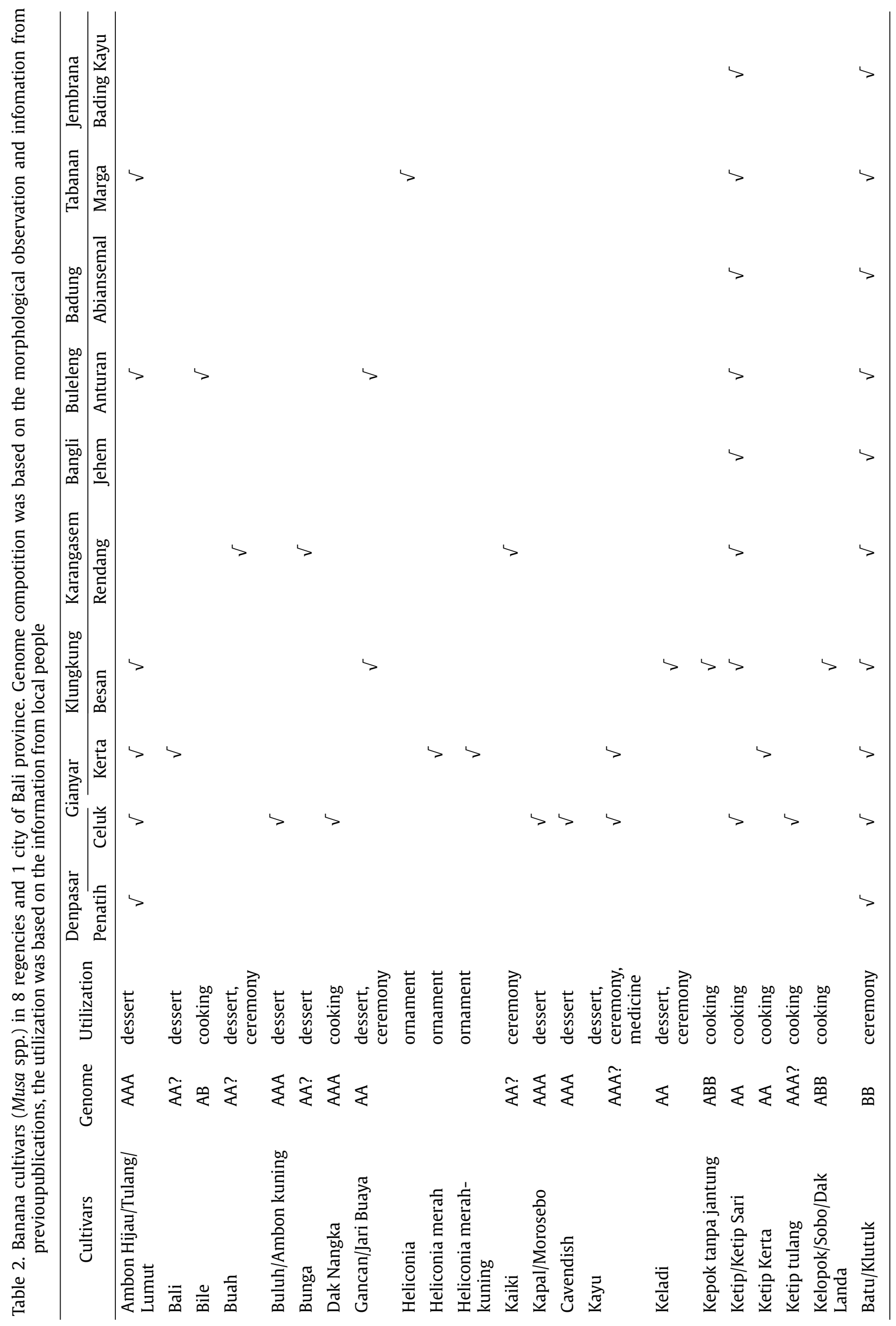




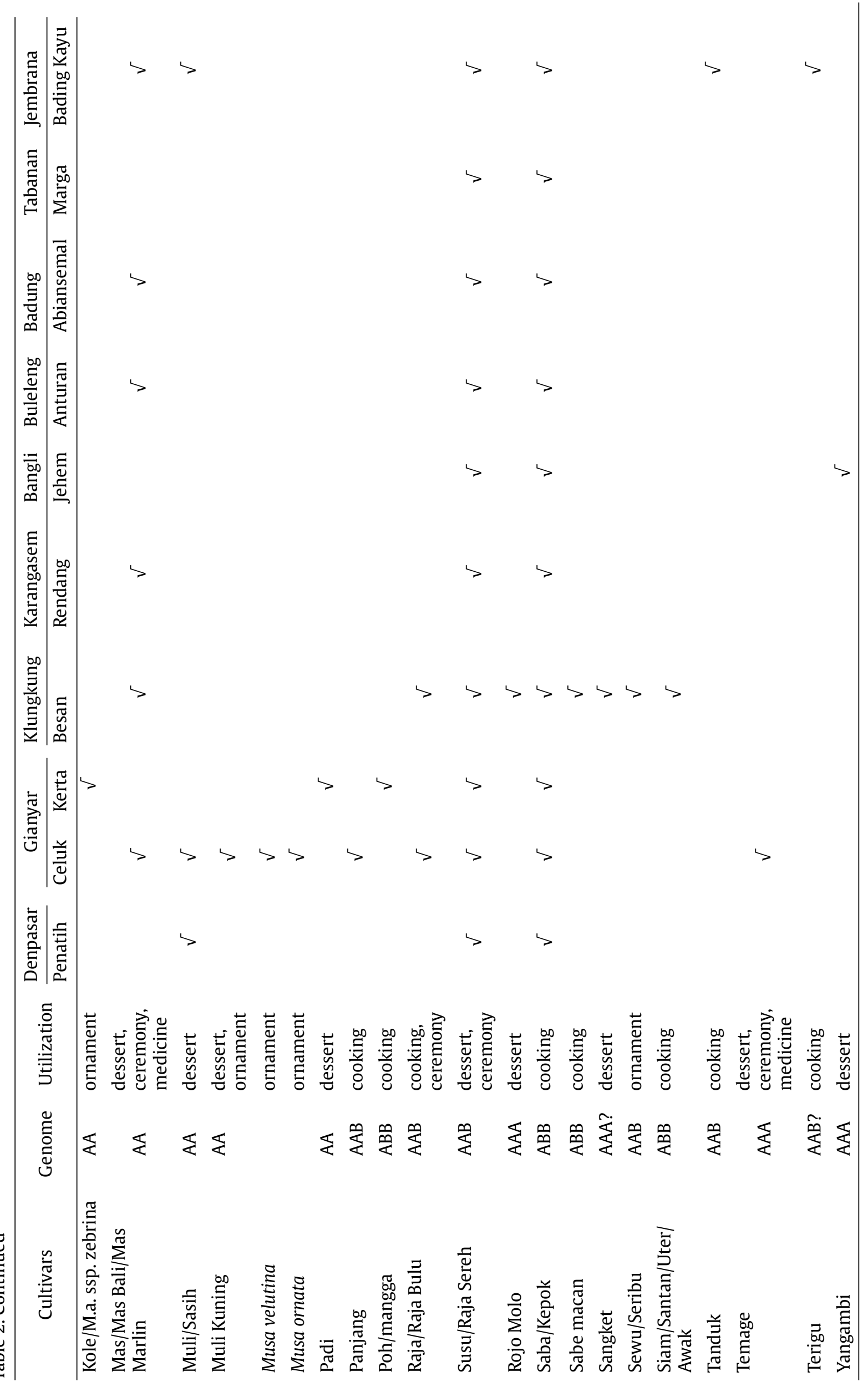



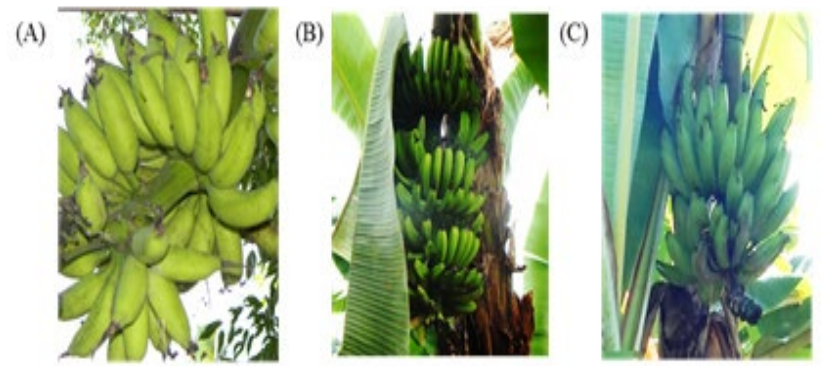

(D)
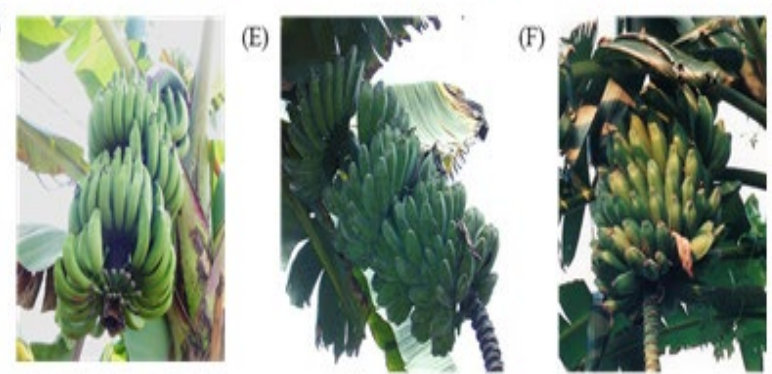

(G)

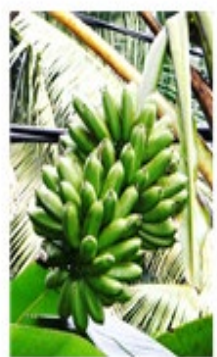

Figure 2. Fruits of the cultivars of most used bananas in Bali. Fruit of (A) biu susu, (B) biu lumut, (C) biu buluh, (D) biu kayu, (E) biu saba, (F) biu batu, and (G) biu mas were characterized in this presented study

Furthermore, out of the seven listed important banana cultivars, only biu kayu is unique to Bali, since the others six were also found in East Java (Hapsari et al. 2017) or Madura (Hapsari et al. 2015). In the present study, Biu kayu was listed in three categories of use (dessert, ceremonies and medicine), which implies the significant role of the cultivar for the locals. This cultivar is also considered as rare genetic resources (BPTP 2017). Despite the high demand for the fruits, it is getting harder and harder to get daily supply of biu kayu. Hence, to promote cultivation of biu kayu would also benefit the conservation effort of this Bali special banana.

Results obtained from this research showed that there are 43 cultivars of banana present in the representing villages of each 8 regencies and 1 city of Bali province. Out of those 43 cultivars, seven were highly used by the people of Bali which are biu susu, biu lumut, biu buluh, biu kayu, biu saba, biu batu, and biu mas. To promote the cultivation of these seven important cultivars could be the solution to reduce importing bananas from outside to meet the daily demand in Bali. Moreover, to promote the cultivation and production of the 7 important cultivars would also improve the economic condition of the farmers and all parties involved in banana-based trades or industries. Among the seven cultivar proposed, biu kayu is unique to Bali and already listed as rare genetic resource. Cultivating this cultivar would not only be financially beneficial, as it is important in medicine and ceremonies group, but also would assist the conservation effort. However, a further study with a wider area is required to generate a comprehensive list of diversity of Bali bananas and determine the land suitability for each cultivar, promoting better cultivation and production.

\section{Acknowledgements}

The authors would like to thank Universities Udayana as the funding institution for this first expedition/study of Bali International Research Center for Banana. Sincere thanks to all the assistants in biodiversity study, Carolin and M. Rifki Ramadhan.

\section{References}

[BPTP] Balai Pengkajian Teknologi Pertanian. 2017. Pisang kayu sumber daya genetik yang semakin langka. http://bali.litbang.pertanian.go.id/ind/index.php/ berita/43-info-aktual/746-pisang-kayu-sumberdaya-genetik-yang-semakin-langka. Bali, Indonesia. [Data accessed: 19 September 2017]

Convention on Biological Diversity. 2017. IndonesiaCountry Profile https://www.cbd.int/countries/ profile/default.shtml?country=id. Montreal, Canada. [Data accessed: 22 september 2017].

De Langhe E et al. 2009. Why Bananas Matter: An introduction to the history of banana domestication. Ethnobotany Research and Application 7:15-47.

Fandika IR et al. 2014. Banana irrigation management and optimization: A comparative study of researchermanaged and farmer managed irrigated banana production in Shire Valley, Malawi. African Journal of Agricultural Research 9:2687-2693. DOI:10.5897| AJAR09.302.

Habit. 2016. Denpasar datangkan pisang dari Jawa. Bali Tribune. http://balitribune. co.id/content/denpasardatangkan-pisang-dari-jawa. Bali, Indonesia. [Data accessed: 19 September 2017].

Hapsari L et al. 2015. Diversity of bananas (Musa spp.) in Madura Island, East Java: exploration and inventory. Journal of Biology and Environmental Sciences 6:256264.

Hapsari L et al. 2017. Ethnobotanical survey of bananas (Musaceae) in six districts of East Java, Indonesia. Biodiversitas 18:160-174.

Hidayat T et al. 2018. Survey of ethnobotanic value of Banana (Musa spp; Musaceae) in Bali Province, Indonesia. Hayati J Biosci 25:31-39

Honfo FG et al. 2011. Banana and plantain-based foods consumption by children and mothers in Cameroon and Southern Nigeria: A comparative study. African Journal of Food Science 5:287-291. 
[IPGRI] International Plant Genetic Resources Institute. 1996. Centre de Cooperation Internationale en Recherche Agronomique pour le Developpement (CIRAD) and International Network for the Improvement of Banana and Plantain (INIBAP). Descriptors for banana (Musa spp.). IPGRI: Rome.

Kennedy J. 2009. Bananas and people in the homeland of Genus Musa: not just pretty fruit. Ethnobotany Research E Applications 7:179-197.

Li LF et al. 2013. Origins and domestication of cultivated banana inferred from chloroplast and nuclear genes. PLOS ONE 8:80502. doi:10.1371/journal. pone.0080502.
Lugrayasa IN. 2004. Pelestarian pisang dan manfaat dalam upacara adat Hindu Bali. Proceeding of seminar on the plant conservation used in Hindu religious ceremony [Indonesian].

Mohapatra D et al. 2010. Banana and its by-product utilisation: an overview. Journal of Scientific $\mathcal{E}$ Industrial Research 69:323-329.

Solikin M. 2010. Islamic aspects in Javanese rites and ceremonies. Yogyakarta: Narasi Publisher.

Suparyana PK. 2016. Analisis permintaan buah pisang di Kota Denpasar, Bali [Tesis]. Universitas Udayana: Magister Program Studi Agribisnis. 